\title{
PERTUMBUHAN TANAMAN JATI CEPU DAN MUNA PADA AREAL KESATUAN PENGELOLAAN HUTAN (KPHL) DI KAMPUNG DERNAFI KABUPATEN BIAK NUMFOR
}

\section{(Growth Attributes of Teak Species Emanating from Cepu and Muna in Protected Forest Management Unit of Biak Numfor)}

\author{
PENIAS ITLAY ${ }^{1}$, NUNANG LAMEK MAY ${ }^{1 凶}$, MARIANA H. PEDAY ${ }^{1}$ \\ Jurusan Kehutanan, Fakultas Kehutanan Universitas Papua Manokwari, Papua Barat, 98314. \\ Tlp/Fax: +62986211065. \\ Penulis Korespondensi: Email: nunangmay@gmail.com \\ Diterima: 13 Agust 2020| Disetujui:09 Okt 2020
}

\begin{abstract}
Abstrak. Penelitian ini bertujuan untuk mengetahui tingkat keberhasilan tumbuh tanaman Jati (Tectona grandis Linn. f.) yang berasal dari Muna dan Cepu di areal Kesatuan Pemangkuan Hutan Lindung Biak Numfor. Berdasarkan hasi penelitian di temukan bahwah pertumbuhan tanaman Jati asal Muna memiliki persentase lebih besar $(77,33 \%)$ dari dari Jati Cepu (64,53\%). Rata-rata pertumbuhan diameter dan tinggi Jati asal Cepu dan Muna diketahui Jati Cepu memiliki rata-rata diameter lebih besar $(5.11 \mathrm{~cm})$ dari Jati Cepu $(4.89 \mathrm{~cm})$. Rata-rata tinggi jati Muna memiliki rata-rata tinggi lebih besar $(5,35 \mathrm{~cm})$ dari Jati Cepu $(4,88 \mathrm{~cm})$.
\end{abstract}

Kata kunci: Pertumbuhan tanaman, jenis jati, keberhasilan tumbuh, diameter, tinggi

\begin{abstract}
The study is focusing on finding out the successful rate of teak (Tectona grandis Linn. f.) growth emanating from Muna and Cepu in protected forest management unit of Biak Numfor. The result pointed out that Teak from Muna has a higher percentage (77.33\%) compared with Cepu teak (64.53\%). The average diameter growth, Cepu teak possess bigger diameter of $5.11 \mathrm{~cm}$ compared with Cepu teak with only $4.89 \mathrm{~cm}$. In addition to the height growth, Muna teak was higher with the average of $5.35 \mathrm{~cm}$ ) than Cepu teak with only $4.88 \mathrm{~cm}$.
\end{abstract}

Keywords: Plant growth, teak species, success of growth, diameter, height

\section{PENDAHULUAN}

Hutan adalah sebuah kawasan yang ditumbuhi dengan lebat oleh pepohonan dan tumbuhan lainnya. Kawasan-kawasan semacam ini terdapat di wilayah-wilayah yang luas di dunia dan berfungsi sebagai penampung karbon dioksida (carbon dioxide sink), habitat hewan, modulator arus hidrologika, serta pelestari tanah, dan merupakan salah satu aspek biosfer Bumi yang paling penting.hutan adalah bentuk kehidupan yang tersebar di seluruh dunia. Kita dapat menemukan hutan baik di daerah tropis maupun daerah beriklim dingin, di dataran rendah maupun di pegunungan, di pulau kecil maupun di benua besar (Mayrowani dan Ashari 2011).

Berdasarkan hasil penafsiran citra satelit Landsat 7 ETM+ Tahun 2011, total daratan Indonesia yang ditafsir adalah sebesar \pm 187.840,9 Juta ha, dengan hasil sebagai berikut : Areal berhutan : 98.072,7 juta ha $(52,2 \%)$ Areal tidak berhutan : $89.768,9$ juta ha $(47,8 \%)$ (Kementrian Kehutanan 2014).

Luas kawasan hutan Papua secara keseluruhan adalah 42.224.480 Ha, namun sejak terbentuknya Provinsi Papua Barat, maka 
kawasan hutan Papua juga terbagi mengikuti batas administrasi pemerintahan Provinsi Papua dan Papua Barat. (SK Menhutbun No.891/KptsII/1999). Luas kawasan hutan Papua 30.272.358 sedangkan luasan kawasan hutan di Provinsi Papua Barat tahun 2007 tercatat seluas 9.769.686,81 ha.Wilayah Papua memiliki hutan hujan tropis, sehingga sangat dipengaruhi oleh suhu yang cukup tinggi sepanjang tahun disertai dengan tidak terdapatnya perubahan iklim yang mencolok.

Saat ini kondisi hutan banyak mengalami kerusakan akibat pemanfaatan yang berlebihan tanpa memperhatikan aspek keberlanjutannya. Hal ini diperparah dengan lahan-lahan hutan untuk pembangunan infrastruktur. Hutan memiliki potensi untuk merehabilitasi dirinya secara alami namun waktu yang dibutuhkan untuk proses ini sangat lama, butuh campur tangan manusia untuk mengembalikan fungsi hutan yang telah terdegradasi.

Penanaman langsung pada areal yang terdegradasi merupakan salah satu tindakan aksi yang dapat dilakukan untuk memperbaiki kerusakan hutan. Agar kegiatan penanaman dapat berhasil dengan baik, perlu dipertimbangkan faktor-faktor seperti: tanaman yang digunakan, kondisi tempat tumbuh dan prospek bagi masyarakat. Pemilihan jenis untuk kegiatan penanaman saat ini diarahkan pada jenis-jenis yang secara ekologis menguntungkan tetapi juga bernilai komersil. Untuk mensukseskan program tersebut, digunakan jenis-jenis endemik maupun eksotik.

Jati (Tectona grandis Linn F) merupakan tanaman eksotik yang ditanam di Papua. Tanaman ini tergolong jenis dengan sifat kekuatan dan keawetan yang tinggi. Pemanfaatannya lebih banyak untuk bahan bangunan, furnitur maupun barang kerajinan. Widyastuti dan Sumardi (2004), menyampaikan bahwa, kayu Jati dapat digunakan sebagai wadah berbagai jenis produk industri kimia karena memiliki daya tahan terhadap berbagai bahan kimia. dengan banyaknya keunggulan yang dimiliki menyebabkan permintaan akan jenis ini terus berlangsung.

Perbanyakan tanaman Jati dapat dilakukan secara generatif maupun vegetatif. Metode perbanyakan dikembangkan pada dasarnya bertujuan untuk mempersiapkan bibit dalam jumlah yang cukup untuk menunjang keberlangsungan proses penanaman di lapangan. Daerah penanaman Jati paling banyak terkonsentrasi di pulau Jawa. Saat ini telah dilakukan penanaman tanaman Jati di luar pulau Jawa dalam jumlah yang besar. Penelitian ini bertujuan untuk mengetahui pertumbuhan Jati Cepu (Tectona grandis Linn F) asal Cepu dan Muna yang ditanam di areal Kesatuan Pemangkuan Hutan Lindung (KPHL) Dernafi Biak Numfor.

\section{METODOLOGI PENELITIAN}

Penelitian ini dilaksanakan di kampung Dernafi Distrik Biak Utara Kabupaten Biak Numfor Provinsi Papua, berlangsung selama 1 (satu) bulan yaitu dari tanggal 9 Juli -10 Agustus 2015.

\section{Alat, Bahan dan Objek Penelitian}

Alat yang digunakan dalam penelitian antara lain: parang, GPS, kamera digital, haga, alat tulis menulis, papan lapangan, rol meter dan kalkulator. Bahan yang digunakan dalam penelitian antara lain tally sheet. Sedangkan objek yang diamati adalah tanaman Jati asal Cepu dan Muna.

Metode yang digunakan dalam penelitian adalah metode deskripsi, dengan teknik obsevasi lapangan.

\section{Variabel Pengamatan}

Variabel yang diamati dalam penelitian ini adalah :
a. Jumlah tanaman yang ditanam
b. Jumlah tanaman yang hidup
c. Diameter tanaman
d. Tinggi tanaman 
e. Kondisi fisik di lapangan (Topografi, tanah dan iklim, dll)

\section{Prosedur Penelitian}

Tahapan dalam melaksanakan penelitian ini adalah:

1. Mengumpulkan informasi tentang asal usul benih, lokasi pengamatan, tahun tanam, jarak tanam, dan luas areal

2. Melakukan survei awal untuk menentukan jalur pengamatan

3. Pengambilan data

\section{Pengolahan Data}

Data dari tiap variabel yang diamati dihitung dengan rumus sebagai berikut :

1. Tanaman Hidup $(\%)=$

$\frac{\text { Jumlah Tanaman Secara Fisik Hidup }}{\text { Jumlah Tanaman Yang Ditanam }} \times 100 \%$

2. Rata-Rata Tinggi Tanaman $(\mathrm{m})=$

$\frac{T t 1+T t 2+\cdots T t n}{N}$

Dimana:

Tt1 = Tinggi Tanaman ke- $\mathrm{i}$

Ttn = Tinggi Tanaman ke $-n$

$\mathrm{N} \quad=$ Jumlah Tanaman

3. Rata-rata Diameter tanaman $=$

$D t 1+D t 2+D t 3+\cdots D t n$

Dimana:

$$
\text { N }
$$

Dt1 = Diameter Tanaman ke -al

Dtn = Diameter Tanaman ke- $\mathrm{n}$

$\mathrm{N} \quad=$ Jumlah Tanaman

\section{Analisa Data}

Data yang diperoleh selanjutnya diolah dan disajikan dalam bentuk tabulasi dan gambar.

\section{HASIL DAN PEMBAHASAN}

\section{Keberhasilan Hidup Tanaman Jati}

Luas wilayah yang ditanami Jati Cepu dan Muna oleh kesatuan Pemangkuan Hutan Lindung (KPHL) kampung Dernafi Distrik Biak Utara seluas 2 ha, terdiri dari luasan penanaman Jati Muna sebesar 1ha dan Jati Cepu sebesar 1ha. Ukuran awal bibit saat penanaman berkisar antara 20-50 cm. Keberhasilan hidup tanaman Jati tersaji pada Tabel 1. Berdasarkan Tabel 1 diperoleh informasi bahwa total jumlah tanaman Jati Cepu yang ditanam dalam 17 Jalur adalah sebanyak 578 bibit. Total jumlah tanaman yang hidup adalah sebanyak 373 tanaman (64,53\%) sedangkan jumlah tanaman yang mati sebanyak 205 bibit $(37,47)$. Jika dilihat persentase hidup berdasarkan jalur maka persen keberhasilan tanaman Jati Cepu yang paling rendah pada jalur 1 (2,94\%). Sedangkan persentase hidup tertinggi terdapat pada jalur 5 dan $11(88,24 \%)$.

Data menujukkan bahwa terdapat dua jalur tanaman (jalur 1 dan 2) memiliki persentase hidup kurang dari $50 \%$. Sembilan jalur lainnya (jalur 3, 4, 7, 8, 13, 14, 15, 16 dan 17) memiliki persentase hidup lebih dari $50 \%$ dan kurang dari 70\%. Enam jalur lainnya (jalur 5, 6, 9, 10, 11 dan 12) memiliki persen keberhasilan hidup lebih dari $70 \%$. Persen hidup secara keseluruhan dari total jumlah tanaman yang di tanam yaitu sebesar 64,53\%. Pertumbuhan menujuk pada penambahan ukuran yang tidak dapat balik, pertumbuhan suatu tanaman secara umum biasanya diukur dengan parameterparameter tinggi pohon, diameter pohon, berat kering, dan lain-lain (Harjadi, 1993 dalam Faisal 2009). Adapun untuk mengukur kondisi fisik tanaman dapat didekati dengan mengetahui beberapa parameter yang mencirikan kwalitas tanaman yaitu: pertumbuhan tinggi, pertumbuhan diameter dan lain-lain.

Berdasarkan Tabel 1 diperoleh informasi bahwa total jumlah tanaman Jati asal Muna yang ditanam dalam 17 Jalur adalah sebanyak 578 bibit $(77,34 \%)$. Total jumlah tanaman yang hidup adalah sebanyak 447 tanaman $(22,66 \%)$. Jumlah tanaman yang mati sebanyak 131 bibit. Jika dilihat persentase hidup berdasarkan jalur maka persen keberhasilan tanaman Jati Muna 
yang paling renda pada jalur 1 (52.94\%). Persentase hidup tertinggi terdapat pada jalur $13(97.06 \%)$. Data menujukkan bahwa terdapat empat jalur tanaman (jalur 1,3, 4, 5) memiliki persentase hidup lebih dari $50 \%$ dan kurang $70 \%$. Enam jalur lainnya (jalur 2, 6, 7, 8, 9, 10, $11,12,13,14,15,16$ dan 17) memiliki persen keberhasilan hidup lebih $70 \%$ persen.

Tabel 1. Tingkat keberhasilan hidup tanaman Jati Capu dan Jati Muna yang di tanam

\begin{tabular}{lcccccc}
\hline No & \multicolumn{5}{c}{ Tanaman Jati Cepu } & \multicolumn{3}{c}{ Tanaman Jati Muna } \\
\cline { 2 - 7 } & $\begin{array}{c}\sum \text { yang } \\
\text { ditanam }\end{array}$ & $\begin{array}{c}\sum \text { yang } \\
\text { hidup }\end{array}$ & $\begin{array}{c}\text { Persentase hidup } \\
(\%)\end{array}$ & $\begin{array}{c}\text { Nyang } \\
\text { ditanam }\end{array}$ & $\begin{array}{c}\sum \text { yang } \\
\text { hidup }\end{array}$ & $\begin{array}{c}\text { Persentase hidup } \\
(\%)\end{array}$ \\
\hline 1. & 34 & 1 & 2,94 & 34 & 18 & 52,94 \\
2. & 34 & 11 & 32,35 & 34 & 24 & 70,59 \\
3. & 34 & 22 & 64,71 & 34 & 21 & 61,76 \\
4. & 34 & 19 & 55,88 & 34 & 20 & 58,82 \\
5. & 34 & 30 & 88,24 & 34 & 21 & 61,67 \\
6. & 34 & 25 & 73,53 & 34 & 27 & 79,41 \\
7. & 34 & 22 & 64,71 & 34 & 26 & 76,47 \\
8. & 34 & 23 & 67,65 & 34 & 31 & 91,18 \\
9. & 34 & 29 & 85,29 & 34 & 29 & 85,29 \\
10. & 34 & 27 & 79,41 & 34 & 29 & 85,29 \\
11. & 34 & 30 & 88,24 & 34 & 29 & 85,29 \\
12. & 34 & 26 & 76,37 & 34 & 29 & 85,29 \\
13. & 34 & 22 & 64,71 & 34 & 33 & 97,06 \\
14. & 34 & 22 & 64,71 & 34 & 28 & 82,35 \\
15. & 34 & 21 & 61,76 & 34 & 30 & 88,24 \\
16. & 34 & 21 & 61,76 & 34 & 28 & 82,35 \\
17. & 34 & 22 & 64,71 & 34 & 24 & 70,59 \\
& & $\sum 373$ & 64,53 & & $\sum 447$ & 77,34 \\
\hline
\end{tabular}
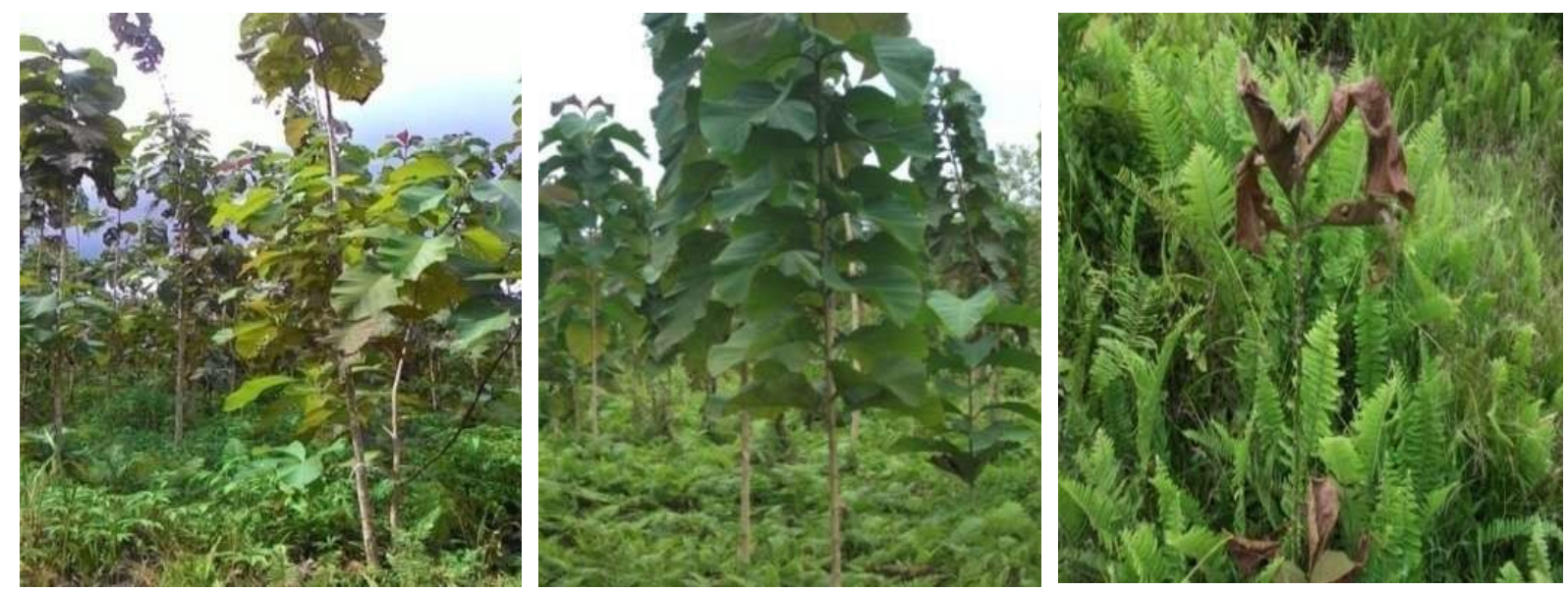

Gambar 1. Penampakan tanaman Jati Cepu dan Muna pada lokasi penanaman KPHL 


\section{Pertumbuhan Diameter Tanaman Jati}

Pertumbuhan rata-rata diameter tanaman Jati Cepu terendah terdapat di jalur $1(2,00 \mathrm{~cm})$ dan tertinggi pada jalur $5(10,57 \mathrm{~cm})$.terhadap 6 jalur pengamatan (jalur 1, 2, 3, 4, 12 dan 15.) memiliki diameter kurang dari $5 \mathrm{~cm}$. Data penelitian menujukan bahwa 10 jalur $(6,7,8,9$, $10,11,13,14,16$ dan 17) memiliki petumbuhan rata-rata diameter $>5 \mathrm{~cm}$ dan $<6$ $\mathrm{cm}$. Hanya pada satu jalur yakni jalur 5 memiliki data-rata diameter sebesar $10,57 \mathrm{~cm}$.

Pertumbuhan rata-rata diameter tanaman Jati Muna terendah ditemukan pada jalur $1(3,05$ $\mathrm{cm})$ dan tertinggi berada pada jalur $14(6,25$ $\mathrm{cm}$ ) terdapat 10 jalur (jalur 1, 2, 3, 4, 5, 6, 7, 8, 9 dan 12) jalur memiliki rata-rata diameter kurang dari $5 \mathrm{~cm}$. Sedangkan terdapat 7 jalur pengamatan (jalur 10, 11, 13, 14, 15, 16 dan 17) memiliki rata-rata diameter sekitar $6 \mathrm{~cm}$ dan dibawah $7 \mathrm{~cm}$. Pertambahan dimensi diameter Jati Cepu secara keseluruhan dari total jumlah tanaman yang di tanama yaitu sebesr $5,11 \mathrm{~cm}$ dan Jati Muna sebesar 4,89 cm.

Pertumbuhan diameter batang sangat dipengaruhi oleh kondisi kambium dan produksi fotosintesis. Menurut Harjadi (1997) dalam Faisal 2009 pertumbuhan lingkar batang berkayu merupakan hasil pertumbuhan meristem. Fahn (1982) dalam Faisal 2009, menyatakan bahwa pertumbuhan diameter adalah hasil dari pembelahan sel kambium xylem sekunder dan floem sekunder, dimana sel-sel floem sekunder berkembang kearah luar dan xylem sekunder berkembang kearah dalam. Menurut Daniels dkk. (1987) dalam Faisal 2009, menyatakan bahwa aktifitas sangat tegantung dari kondisi tajuk tanaman yang terbentuk. Pertumbuhan pucuk yang cepat dan perkembangan daun selanjutnya menimbulkan produksi auksin sehingga meningkatkan pertumbuhan diameter.

\section{Pertumbuhan Meninggi tanaman Jati}

Pertumbuhan rata-rata dimensi tinggi tanaman Jati Cepu terendah terdapat di jalur 1
$(2,00 \mathrm{~cm})$ dan tertinggi pada jalur $10(5,78 \mathrm{~cm})$. Sedangkan dari 5 jalur pengamatan $(1,2,3,4$ dan 15.) memiliki diameter dibawah $5 \mathrm{~cm}$. Data penelitian menunjukkan bahwa dari 12 jalur pengamatan (jalur 5, 6 , 7, 8, 9, 10, 11, 12, 13, $14,16,17)$ memiliki petumbuhan rata-rata tinggi lebih dari $5 \mathrm{~m}$ dan $<6 \mathrm{~m}$.

Pertumbuhan rata-rata tinggi tanaman Jati Muna terendah pada jalur $1(3,50)$ dan tertinggi pada jalur $14(6,60)$ hasil pengamatan memperlihatkan bahwa pada 7 jalur yakni jalur $1,2,4,5,7,8$ dan 9, memiliki rata-rata diameter $<5 \mathrm{~m}$. Sementara pada empat jalur pengamatan $(3,6,12$ dan 15) memiliki rata-rata tinggi $>5 \mathrm{~m}$ dan $<6 \mathrm{~m}$. Terdapat 6 jalur pengamatan (jalur 10, 11, 13, 14, 15, 16 dan 17) memiliki rata-rata tinggi $>6 \mathrm{~m}$ dan $<7 \mathrm{~m}$. Pertambahan dimensi tinggi tanaman Jati Cepu secara keseluruhan dari total jumlah tanaman yang ditanam yaitu sebesar $4,88 \mathrm{~m}$ dan Jati Muna sebesar 5,35 m.

Pertumbuhan tinggi suatu tanaman menurut Daniels dkk (1987) dalam Faisal (2009) tergantung pada jumlah cadangan karbohidrat yang tersimpan dalam tanaman serta air yang terserap. Harjadi (1979), dalam Faisal 2009 menyatakan bahwa selama proses proses vegetatif perpanjangan sel membutukan karbonhidrat dan air yang banyak, sedangkan menurut Gardner dkk.(1991), tanaman bertambah tinggi adalah merupakan aktifitas meristem ujung yang menghasilkan sel-sel baru yang terletak tepat dibelakang titik tumbuh.

Suatu cara untuk mendapatkan suatu tanaman yang berkualitas baik, tahan terhadap hama penyakit perlu diketahui sifat-sifat genetika tanaman dengan cara melakukan pemulian tanaman. Disini sifat genetik suatu jenis tanaman memegang peranan penting dalam pertumbuhan dan kwalitas tanaman. Dibawah kondisi kesuburan tanah yang rendah, tanaman tidak mampu berkembang sempurna sekalipun tanaman tanaman hasil pemuliaan jadi factor genetik hanya dapat dipertahankan 
kalau faktor lingkungan menunjang (Benarto, 1997 dalam Faisal 2009).

Faktor lingkungan yang mempengaruhi pertumbuhan dan kualitas tanaman yaitu tanah, cahaya, curah hujan, mutu, atmosfir, suhu dan organisme (Lekitoo et al. 2020). Semua factor lingkungan tersebut tidak dapat berdiri sendiri. Dalam tanaman terjadi fotosintesis yang berjalan optimal bila hara mineral, cahaya, suhu, $\mathrm{O}_{2}$ dan air tersedia optimal (Raharja, 1988 dan bernarto, 1997 dalam Faisal 2009).

Suatu tanaman akan tumbuh dengan baik apabilah segalah elemen yang dibutukan ada dan tersedia cukup. Dengan demikian pertumbuhan suatu tanaman sangat dipengaruhi oleh kesuburan tanah. Kesuburan tanah tergantung pada umur, kedalaman, kedalaman, kapasitas tukar kation tanah. Menurut Poerwidodo (1991) dan sangkalah (1994) dalam Faisal (2009) kesuburan tanah dapat didefinisikan sebagai kemampuan tanah untuk menyediakan kebutuhan tanaman akan zat hara yang diperlukan dalam jumlah yang cukup seimbang dan berkesinambungan.

\section{KESIMPULAN}

Pertumbuhan tanaman Jati asal Cepu dan Muna, pada areal Kesatuan Pemangkuan Hutan Lindung di ketahui Jati Muna memiliki persentase lebih besar $(77,33 \%)$ dari dari Jati Cepu (64,53\%). Rata-rata pertumbuhan diameter dan tinggi Jati asal Cepu dan Muna, pada areal KPHL diketahui Jati Cepu memiliki rata-rata diameter lebih besar $(5,11 \mathrm{~cm})$ dari Jati
Cepu $(4,89 \mathrm{~cm})$. Rata-rata tinggi lebih besar $(5,35 \mathrm{~cm})$ dari Jati Cepu $(4,88 \mathrm{~cm})$. Sedangkan rata-rata tinggi jati Muna memiliki rata-rata tinggi lebih besar $(5,35 \mathrm{~cm})$ dari Jati Cepu $(4,88$ $\mathrm{cm})$.

\section{DAFTAR PUSTAKA}

Faisal 2009. Persentase tumbuh tanamana reboisasi di desa Oransbari dan desa Masabui distrik Oransbari kabupaten Manokwari. Skripsi Sarjana Kehutanan pada Fakultas Kehutanan Universitas Negeri Papua Manokwari. (Tidak diterbitkan).

Lekitoo K, Peday HFZ, Panambe N, Cabuy RL. 2020. Distribution and habitat-specific attributes of Sararanga sinuosa Hemsl., in a low land tropical forest in Indonesian New Guinea. Eurasian Journal of Biosciences, 14 (2): 6255-6260.

Mayrowani H dan Ashari. 2011. Pengembangan agroforestry untuk mendukung ketahanan pangan dan pemberdayaan petani sekitar hutan. Forum Penelitian Agro Ekonomi, 29 (2): 83-98. https://media.neliti.com/media/publications/ 64154-none-cc75e2df.pdf.

Kementrian Kehutanan 2014. Statistik Kementerian Kehutanan Tahun 2013. Jakarta.

Widyastuti dan Sumardi. 2004.Dasar-dasar perlindungan hutan. Gadjah Mada University Press. Yogyakarta. 